\title{
Impact of irrigation on pasture production on two sheep and beef farms in the Central Wairarapa
}

\author{
A.D. MACKAY ${ }^{1}$, P.J. BUDDING ${ }^{1}$ and $\mathrm{J}^{\mathrm{MORTON}^{2}}$ \\ ${ }^{I}$ AgResearch, Grasslands Research Centre, PB 11 008, Palmerston North \\ ${ }^{2}$ Ballance Agri-Nutrients, Box 65, Rolleston \\ alec.mackay@agresearch.co.nz
}

\begin{abstract}
The impact of irrigation on seasonal and annual pasture production was investigated on two sheep and beef farms in the Central Wairarapa over 4 years (2004-08). The pasture response to irrigation water at Brancepeth Station ranging from 37 to $63 \%$ in the first 3 years, while at Glenlean the pasture response was only 22 and $26 \%$ in the 2 years (2004/05 and 2006/07, respectively) the irrigation treatment was imposed. In 2007/08 year to date, the driest of the 4 years, the pasture response up until May had been similar at the two sites $(76 \%$ and $71 \%$ for Glenlean and Brancepeth Station, respectively). If the pattern of pasture growth follows the same trends as in previous years, the benefits of irrigation will continue to be apparent at Brancepeth Station until the late winter/ early spring. This study provides valuable data for farmers and their advisors to assess the impact of irrigation on the seasonal and annual distribution of pasture production.
\end{abstract}

Keywords: water harvesting, irrigation, seasonal water deficit

\section{Introduction}

There are numerous benefits associated with actively managing water rather than accepting the impact of shortterm seasonal water deficits (summer) or surpluses (winter) on the farm business. Increasingly, both internal and external pressures will require the farmers to better manage water excesses and shortages. Climate change, regulations, and economics will demand it.

Pasture growth increases from correcting seasonal soil water deficits in pasture soils through irrigation are well documented (Cosgrove \& Brougham 1988; McBride 1994; Thompson 1996). In dry land environments in Canterbury, McBride (1994) reported annual pasture production increases of $80 \%$ (on average $5.2 \mathrm{t} / \mathrm{ha}$ ) under irrigation. Thompson (1996) found pasture production increases of over $3 \mathrm{t} / \mathrm{ha}$ in the summer in the Waikato under irrigation. Irrigation in hill country environments is complicated by a number of factors that are not major issues on easier downland and the plains (Borrie \& Heiler 1984). These authors identified some of the challenges that must be considered in assessing the economic feasibility of irrigation in hill country, including, the ratio between total farm area and that part of the farm that is topographically suited for irrigation, the broken nature of the landscape, the distance between water source and irrigation block and the lack of data on the pasture and economic response from irrigation.

The east coast of the North Island generally experiences soil water deficits in summer and autumn each year. Predictions by NIWA over the next century are for summer drought conditions to become more prevalent. Summer dry conditions, by limiting pasture growth, limits the options for late spring and summer finishing programmes and puts pressure on capital stock in the months leading up to mating.

On the east coast of the southern North Island where there is sufficient annual rainfall $(>850 \mathrm{~mm})$, the opportunity exists to harvest water from catchment runoff during winter and spring, store it in a dam and use it for irrigating pasture during summer and autumn. Water harvesting is not a new concept and has been advocated for some time as an approach for improving water management on farm (Bowler 1980). The concept of capturing and recycling run-off and drainage water is also not new (Sakadevan et al. 2000), but the concept of using water harvesting as an approach for capturing and retaining sediment and nutrient within the farm boundary has received less attention. Important factors in determining the economic feasibility of water harvesting includes, apart form the distance and gradient between the dam and the irrigation block, the size of the dam and the cost of dam construction. The latter is governed by the shape and the contour of the valley floor, which in turn influences the potential dam wall height and earth moving required. The stability of the landscape, the suitability of material for dam building and the size of the receiving catchment are additional factors governing the viability of on-farm irrigation.

A number of sheep and beef farmers in the central Wairarapa have constructed water harvesting dams in recent years. That interest is growing. A frequently asked question by producers is "What are the size and the duration of pasture production responses to irrigation?" The impact of irrigation on seasonal and annual pasture production, using water harvested and stored in earth dams was investigated on two sheep and beef farms in the Central Wairarapa over 4 years. 


\section{Method}

An on-farm study was initiated in 2004 on two sheep and beef properties (Glenlean, farmed by Mike Southey, and Brancepeth Station by Ed Beetham) in the Central Wairarapa on the East Coast of the southern North Island. On both farms, run-off from winter and spring rainfall is collected behind earth dams built across wide-low valleys and applied through lines (1215 sprinklers/line) of small sprinklers shifted from a fixed point to flat and easy rolling landscape from late spring through to the autumn. Glenlean installed and started operating their irrigation systems (approximately 3 ha dam containing $70,000 \mathrm{~m}^{3}$ water, irrigating a 23 ha pasture block) in 2002/03 and at Brancepeth Station (7 ha dam, $700 \mathrm{~m}$ long and $100 \mathrm{~m}$ wide, irrigating approximately $36.5 \mathrm{ha}$ ) irrigation systems were installed in 2004, but did not start operating until January 2005.

Within a paddock of the irrigated block on each farm, two similar areas were identified and surveyed for uniformity with regards to topography, pasture composition and soil fertility (Table 1). Pasture composition was assessed on a grab sample and soil fertility assessed on 20 soil samples $(0-75 \mathrm{~mm})$ taken from both the irrigated and rain-fed sites on both farms. Bulk density was assessed using stainless steel cores (100 $\mathrm{mm}$ diameter x $75 \mathrm{~mm}$ deep). Water holding capacity was assessed on a $0-75 \mathrm{~mm}$ sieved soil sample. Soil moisture was monitored by TDR (Time domain reflectometry). One of the two areas (approximately $200 \mathrm{~m}^{2}$ at Glenlean and $1000 \mathrm{~m}^{2}$ at Brancepeth Station) was then selected as the control (rain-fed) and the other irrigated, along with the balance of the paddock. The rain-fed area was protected from irrigation and not threatened from surface or subsurface drainage.

At both sites, pasture production was measured on each of these areas every 4 to 11 weeks for 4 years from October 2004 to May 2008 using three to four animal exclusion cages $(1 \mathrm{~m} \times 0.5 \mathrm{~m})$ that were shifted to a new trimmed location after each cut. Pasture in the cage was cut with electric shears, bagged and weighed fresh and a subsample taken for dry matter content, after oven drying $\left(100^{\circ} \mathrm{C}\right)$. There were six, seven, eight and six pasture cuts in 2004/05, 05/06, 06/07 and 07/08 year to date, respectively. Rainfall was monitored at each site in 2004/05 and 2005/06 in rain gauges located within the trial paddock and the amount of water applied by irrigation calculated from the irrigation schedules used on the two farms. From the second half of the 2005/06 season onwards, rainfall and the amount of water applied in irrigation water was monitored using an automatic tipping bucket and data logger.

At Glenlean, a new pasture was drilled in the trial paddock being monitored in spring 2005. To ensure good pasture establishment both the rain-fed and irrigated sites were irrigated throughout 2005/06. At Brancepeth Station the irrigated pasture was 2 years old.

\section{Statistical analysis}

The rain-fed and irrigated treatments were not replicated, so the analysis was limited to a simple $t$-test. A significant difference means the two means are different. It does not necessarily mean there is a significant treatment effect (i.e. to irrigation).

Table 1 Soil and pasture characteristics of the two rain-fed and irrigated sites in the Central Wairarapa.

\begin{tabular}{|c|c|c|c|c|}
\hline \multirow[t]{2}{*}{ Parameter } & \multicolumn{2}{|c|}{ Glenlean } & \multicolumn{2}{|c|}{ Brancepeth Station } \\
\hline & Rain-fed & Irrigated & Rain-fed & Irrigated \\
\hline $\begin{array}{l}\text { Altitude (m a.s.l.) } \\
\text { Soil type }\end{array}$ & \multicolumn{2}{|c|}{$260-280$} & \multicolumn{2}{|c|}{220} \\
\hline $\begin{array}{l}\text { Soil fertility } \\
\text { Olsen } P(\mu \mathrm{g} / \mathrm{ml}) \\
\mathrm{pH} \\
\mathrm{K}\end{array}$ & $\begin{array}{l}30 \\
6.2 \\
3\end{array}$ & $\begin{array}{c}33 \\
6.3 \\
4\end{array}$ & $\begin{array}{c}21 \\
5.6 \\
3\end{array}$ & $\begin{array}{c}25 \\
5.6 \\
5\end{array}$ \\
\hline Bulk density $\left(\mathrm{mg} / \mathrm{cm}^{3}\right)$ & \multicolumn{2}{|c|}{0.87} & \multicolumn{2}{|c|}{1.04} \\
\hline $\begin{array}{l}\text { Water holding capacity (VMC\%) } \\
-10 \mathrm{kPa} \\
-100 \mathrm{kPa}\end{array}$ & \multicolumn{2}{|c|}{$\begin{array}{l}44 \\
29\end{array}$} & \multicolumn{2}{|c|}{$\begin{array}{l}40 \\
30\end{array}$} \\
\hline $\begin{array}{l}\text { Soil moisture content (VMC \%) } \\
23 / 11 / 04 \text { before irrigation commenced }\end{array}$ & 16 & 13 & 22 & 18 \\
\hline $\begin{array}{l}\text { Botanical composition }(23 / 11 / 04) \\
\text { Ryegrass }(L \text {. perenne) } \\
\text { Other grass species } \\
\text { White clover (T. repens) } \\
\text { Sub clover ( } T \text {. subterranean) }\end{array}$ & $\begin{array}{l}41 \\
57 \\
0.5 \\
1.4\end{array}$ & $\begin{array}{c}32 \\
65 \\
3 \\
0\end{array}$ & $\begin{array}{l}74 \\
19 \\
7 \\
0\end{array}$ & $\begin{array}{l}87 \\
5 \\
8 \\
0\end{array}$ \\
\hline $\begin{array}{c}\text { Pasture production (kg DM/ha) } \\
23 / 11 / 04-22 / 12 / 05 \\
07 / 10 / 05-05 / 09 / 06\end{array}$ & 14,300 & 14,300 & 1,070 & 940 \\
\hline
\end{tabular}


Figure 1 Pasture production at the two sites in 2004/05, 05/06, 06/07 and 07/08 year to date. Both the rain-fed and irrigated sites at Glenlean were irrigated in 2005/06. ${ }^{*}$ Significant difference at the $5 \%$ level.

\section{Glenlean}

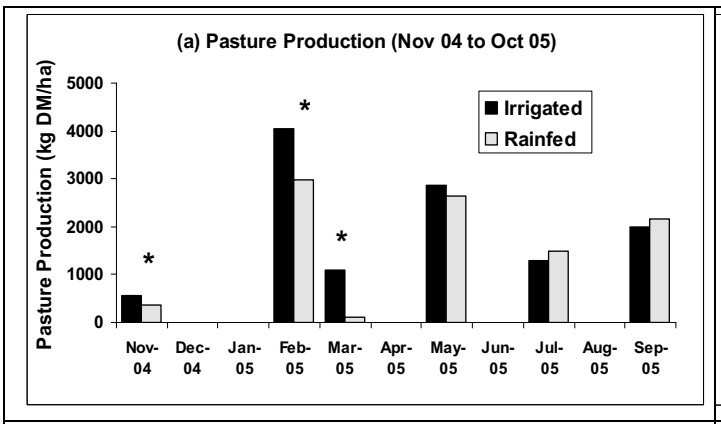

(c) Pasture production (Sept-05-Sept 06)

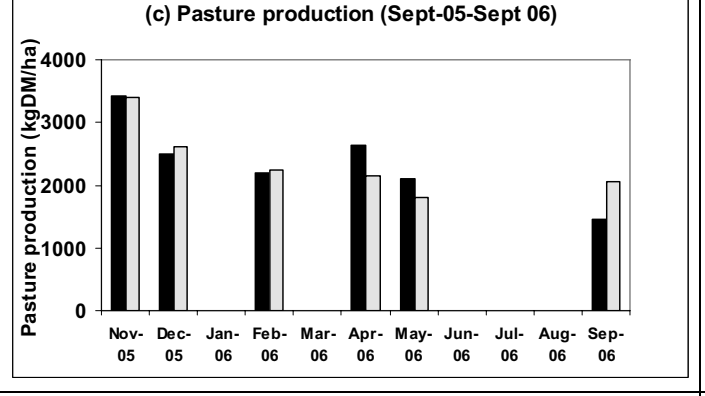

(e) Pasture production (Oct 06-Sept 07)

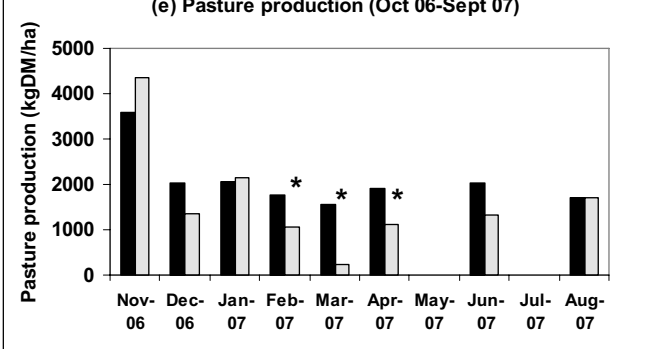

(g) Pasture production (Oct 07-May 08)

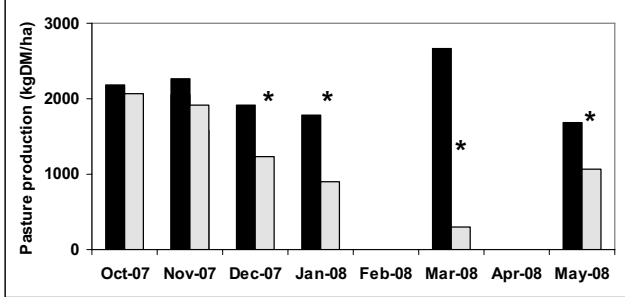

\section{Results and Discussion}

The impact of irrigation on seasonal and annual pasture production is considered at each of the two sites and then the findings from the two sites compared.

\section{Irrigation response on Glenlean}

There was a large $(50 \%)$ pasture response to irrigation in
Brancepeth Station

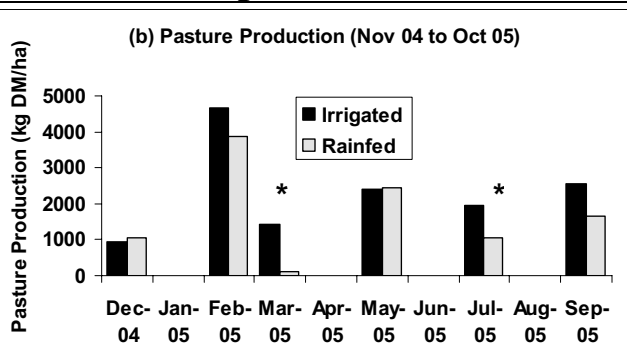

(d) Pasture production (Sept 05-Sept 06)

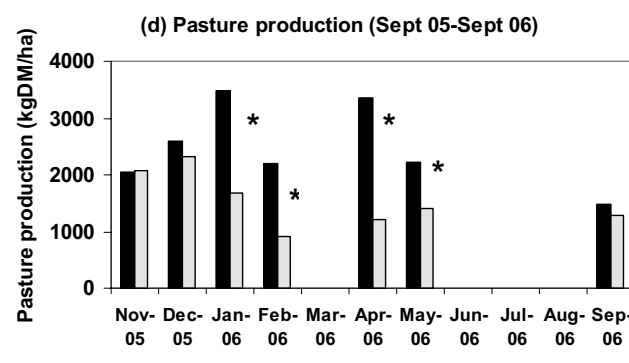

(f) Pasture production (Oct 06- Sept 07)

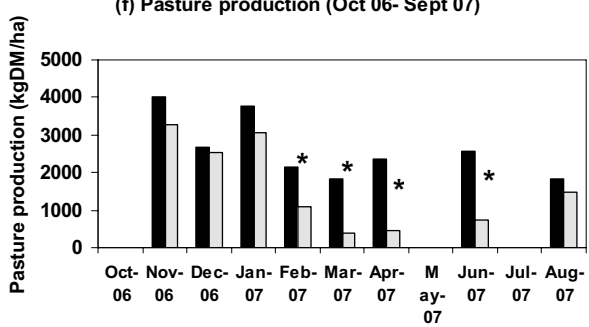

(h) Pasture production (Oct 07-May 08)

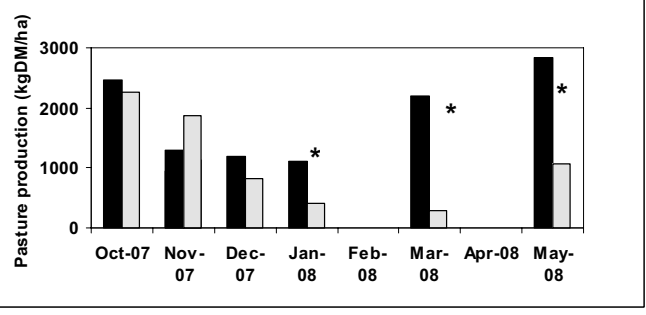

December 2004, despite the cold temperatures throughout the spring (Fig.1a). Annual production (October to September) increased by $22 \%$ in the first year (Table 2). Water use efficiency calculated by dividing the extra pasture production $(2,100 \mathrm{~kg} \mathrm{DM} / \mathrm{ha})$ by the water applied by irrigation $(80 \mathrm{~mm})$ was $26 \mathrm{~kg} \mathrm{DM} / \mathrm{mm}$ irrigation water. With a new pasture drilled in the paddock 
Table 2 Annual pasture production (and percent increase due to irrigation), rainfall and irrigation data at the two irrigation sites in the Central Wairarapa and rainfall data from Castlepoint and the Taueru River at Te Weraiti.

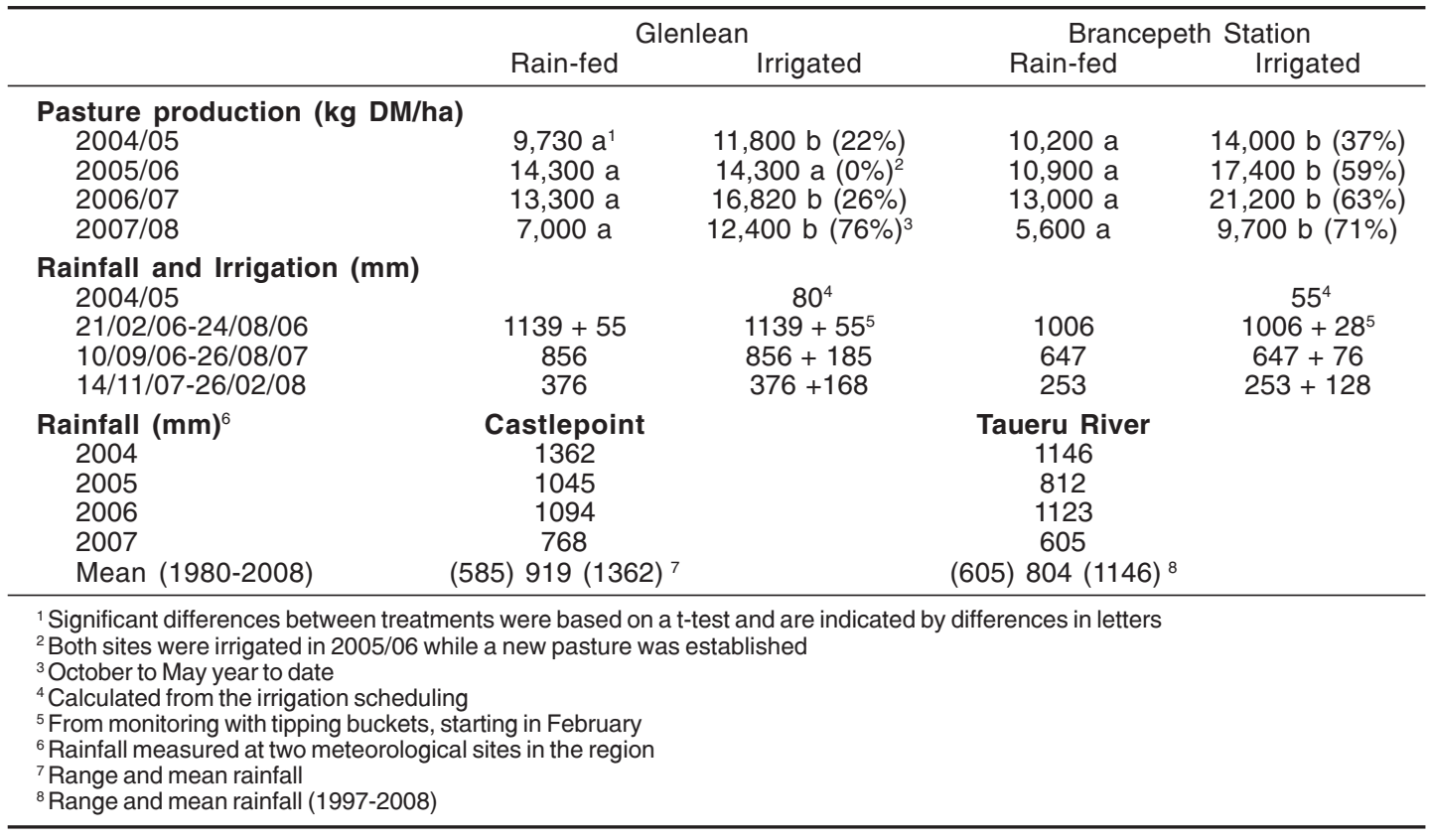

being monitored in spring 2005 , both the irrigated and rain-fed pasture sites were irrigated to ensure good establishment throughout 2005/06. No difference in production was found (Fig. 1c), giving confidence that the differences in later years were attributable to the irrigation treatment. Irrigation offers greater flexibility in the timing of pasture renewal and improves the certainty of successfully establishing a new pasture.

To highlight the variation in the weather patterns that prevailed during the study, one irrigation event took place in September 2006 following a very dry winter. This was followed by a cold wet spring with the irrigator not used again until late December. That year (2006/07), pasture production was increased by $26 \%$, similar to that found in 2004/05 (Table 2). Dry matter content of the irrigated pastures was less than half that of the rain-fed pasture during the late summer (Fig. 2c), reflecting the increased growth and greater amounts of green leaf. Water use efficiency if limited to the time irrigation water was applied, was $15 \mathrm{~kg} \mathrm{DM} / \mathrm{mm}$ of water, increasing to 19 if pasture growth in the 6 weeks following the cessation of irrigation was included.

To date in the current year (October 07 to May 08), there has been a $76 \%$ pasture response to irrigation with production lifted from 7700 to $12,400 \mathrm{~kg} \mathrm{DM} / \mathrm{ha}$ (Fig.1g). Irrigation stopped in late February with the use of the last of the water in the irrigation dam. The water use efficiency up until the time the irrigator was turned off was $14 \mathrm{~kg} \mathrm{DM} / \mathrm{mm}$ of water, increasing to $32 \mathrm{~kg} \mathrm{DM} /$ $\mathrm{mm}$ of water if the benefit of irrigation was calculated from the accumulative benefit through to May.

\section{Irrigation response on Brancepeth Station}

The irrigation system was not operational until late January 2005. Due to the delay in the start of irrigation, the pasture growth measure in December 2004 provided some evidence that the rain-fed and irrigated sites had similar pasture growth characteristics (Table 1, Fig. 1). This gives some confidence that the differences in later years could be attributable to the irrigation treatment. There was a large pasture response to irrigation in February and early March 2005 (Fig. 1b), with annual pasture production increased by $37 \%$ (Table 2 ). Water use efficiency calculated for the period water was applied by irrigation to the end of March was $26 \mathrm{~kg} \mathrm{DM} / \mathrm{mm}$ irrigation water, increasing to $68.5 \mathrm{~kg} \mathrm{DM} / \mathrm{mm}$ if calculated for the 12 months.

In the first full year of irrigation $(2005 / 06)$, pasture production increased by $59 \%$ (Fig. 2d; Table 2). Pasture production gains on the irrigated pasture occurred in the 2005 winter, long after the irrigator had been turned off. This was again the case in 2006 (Fig. 1f) and 2007 (Fig. 1h). Associated with the higher growth rates on the irrigated pasture, was a lower dry matter content in 2005, 2006 and 2007 (Fig. 2). A feature at Brancepeth Station was the higher soil moisture contents in the irrigated block into the autumn/winter months (Fig. 3b), providing a possible explanation for the continued benefits of 
Figure 2 Pasture dry matter content at the two sites in 2005/06, 2006/07 and 2007/08 year-to-date.

Glenlean

(a) Pasture quality (2005/06)

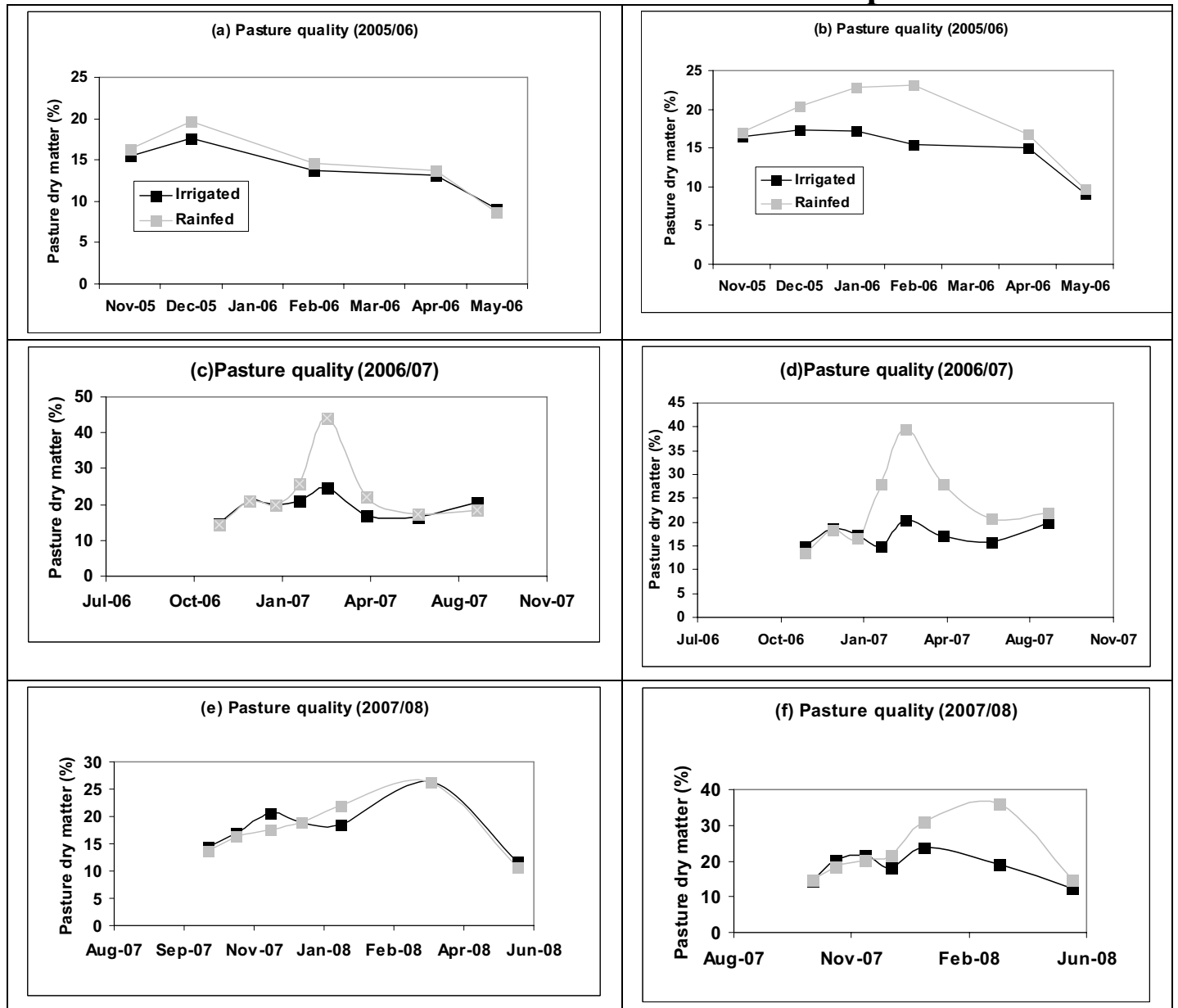

irrigation long after the irrigator had been turned off. In fact soil moistures were much higher at Brancepeth Station (Fig. 3), reflecting a less well drained soil and the position on the landscape the soil is found. In winter, the soil moisture content nears saturation at Brancepeth Station.

In 2007/08, $128 \mathrm{~mm}$ was applied before the irrigator was turned off with the last of water in the irrigation dam used in late April. Up until that point, pasture production had been increased by $71 \%$, in a year with less than half normal rainfall (Fig. 1h; Table 2). The water use efficiency was calculated at $32 \mathrm{~kg} \mathrm{DM} / \mathrm{mm}$ water.

A higher nutrient content of the irrigation water was suggested as an explanation for the continued pasture response to irrigation at Brancepeth Station in the months after the irrigator was turned off, but an analysis of the nitrogen content of the irrigation water at Brancepeth Station ruled that out. Results for the dam water samples were ammonium $\mathrm{N}$ of 0.92 and $0.88 \mu \mathrm{g} \mathrm{N} / \mathrm{ml}$; and nitrate-
$\mathrm{N}$ of 0.1 and $0.11 \mu \mathrm{g} \mathrm{N} / \mathrm{ml}$, which translates into approximately $1 \mathrm{~kg}$ Min N/ha with the application of 100 mm irrigation.

\section{Comparison of the two pasture irrigation sites}

The pasture response to irrigation at Brancepeth Station ranged from $37-63 \%$ in the first 3 years, despite the delay in the start of irrigation in the first year (Table 2). At Glenlean, the pasture response to irrigation was smaller, $22 \%$ in 2004/05 and 26\% in 2006/07 (Table 2). The pasture responses were similar at the two sites in $2007 / 08$ year to date $(76 \%$ and $71 \%$ for Glenlean and Brancepeth Station, respectively). If the pattern of pasture growth follows the same trends as in previous years, the benefits of irrigation will continue to be expressed as extra pasture growth at Brancepeth Station through until late winter and the following spring. At both sites, irrigated pastures continued active growth long after the irrigators were turned off. In comparison the rain-fed 
Figure 3 Volumetric moisture content of the soil in the irrigated and rain-fed plots at the two sites $2004-2008$.

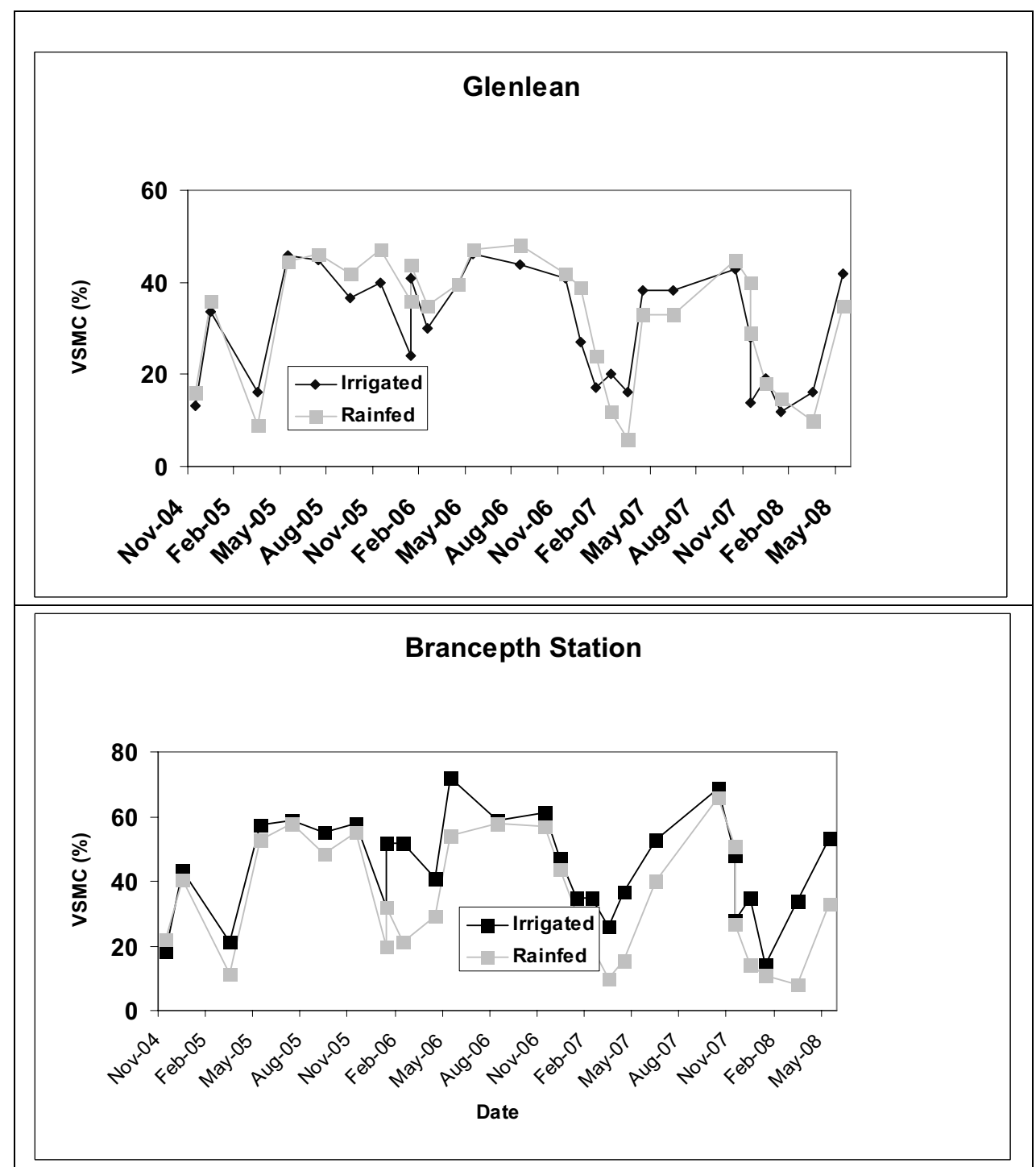

pastures would have to first re-establish root systems, tiller number and leaf area, when the autumn rain arrives. At Brancepeth, rewetting appears to take longer (Fig. 3). If this finding is combined with the fact that the winter conditions that have prevailed in the previous 3 years have been characterised by below average rainfall, the actively growing pasture on the irrigated block may continue to grow at higher rates for an extended period.

\section{Conclusions}

With the prediction that over the next century, drought conditions will be more prevalent on the East Coast of New Zealand, developing a better understanding of the impact of irrigation water on pasture growth and how best that can be used in our farming systems takes on growing importance. In this study the difference in the pasture response between two similar sites highlights that our understanding of the pattern of the pasture response is not fully understood. On both farms, however, the irrigation blocks provide not only an option for growing additional pasture but also peace of mind during conditions that have prevailed in the last 18 months.

\section{ACKNOWLEDGEMENTS}

The authors would like to thank the two participating farmers, Mike Southey (Glenlean) and Ed Beetham (Brancepeth Station), for allowing access to their farms and for their support and ongoing interest in the project. 
The authors would also like thank Ballance Agri-Nutrient for funding this project as part of their investment into pastoral research and Stan Braaksma from the Wellington Regional Council for providing knowledge on the region's resources and for his assistance and ongoing interest in the study.

\section{REFERENCES}

Borrie, D.N.H.; Heiler, T.D. 1984. Irrigation in hill country. A feasibility study in the Hakataramea Valley. New Zealand Agricultural Engineering Institute, Project Report No. 30103 pp.

Bowler, D.G. 1980. The Drainage of Wet Soils Hodder and Stoughton Auckland.

Cosgrove G.P.; Brougham, R.W. 1988. Pasture strategies for dairy beef production. Proceedings of the New Zealand Grassland Association 49: 57-62.

Mackay, A.D.; Sheppard, G.; Woodgyer, W.; Coleman, G. 2007. Total water management - On-farm. FITT Final Report 06FT177.

McBride S.D. 1994. Pasture yield responses to irrigation in Canterbury. Proceedings of the New Zealand Grassland Association 56: 165-168.

Sakadevan, K.; Maheshwari, B.L.; Bavor H.J. 2000. Availability of nitrogen and phosphorus under recycled water irrigated. Australian Journal of Soil Research 38: 653-664.

Thompson, N.A. 1996. Irrigation and pasture quality. pp. 58-66. In: Proceedings 48th Ruakura Farmers Conference, Hamilton, New Zealand. 